\title{
Compliance with Disclosure Requirements under IFRS 3 of Companies Trading at Prague Stock Exchange
}

\author{
Taisia Nistorenco*
}

\begin{abstract}
:
This article analyses compliance with information disclosure requirements under IFRS 3 Business Combinations in 23 companies trading at Prague Stock Exchange. The analysis was performed with the use of publicly available data contained in annual reports of the companies. Beyond quantification of the level of compliance, the research explores which factors affect diligence in following IFRS 3 disclosure requirements, specifically the company size, history of trading on the stock exchange, ownership structure and the acquisition price paid. The literature review also focuses on aspects with a potential to influence the level of diligence in areas of disclosure and consequences of infringing the disclosure rules. The paper concludes that the level of compliance can be considered average and in some cases unsatisfactory, while the company size and longer history of trading on PSE are positively correlated with the quality of disclosure.
\end{abstract}

Key words: IFRS 3 Business Combinations; Disclosure; Czech Publicly Traded Companies; Prague Stock Exchange.

JEL classification: M410, G300

\section{Introduction}

Importance of transparent communication between publicly traded companies and all their stakeholders and the general public is crucial for smooth functioning of capital markets. This also has a considerable impact on the decision making processes of a wide spectrum of economic agents. The most important topics related to disclosure of information in financial reports deal with investors' protection, information asymmetry and agency costs.

The term Business combinations, in the sense it is adopted in IFRS 3 Business combination, encompasses mergers and acquisition of businesses where the acquirer obtains control over the target. A business in this sense is a set of activities and assets that are manageable for the purpose of providing products,

\footnotetext{
* Taisia Nistorenco; University of Economics, Prague, Faculty of Finance and Accounting, Department of Corporate Finance and Business Valuation, W. Churchill Sq. 4, 13067 Prague 3, Czech Republic, <xnist00@vse.cz>.

The article is processed as an output of the research project IG104029 under institutional support of the Faculty of Finance and Accounting, University of Economics, Prague.
} 
goods and/or services to clients and generate different types of income. Adoption of IFRS 3 disclosure requirements follows the goal of increasing the relevance, reliability and comparability of information regarding the business combination and, importantly, its effects. It is especially the effects of disclosure of information regarding business combinations that are important when analysing the level of compliance.

Disclosure of financial and business information regarding mergers and acquisitions is correlated with the general transparency of a given company and often defines its attractiveness to investors. Transparent information environment is key for the capital market's progress. On the opposite, lack of transparency and failure to disclose key information reduce confidence of investors and stakeholders. Thus many financial researchers, including Myers and Majluf (1984), Holland (1998), Hope et al., (2006), Leuz and Verrecchia (2000) and Kothari (2000), find that there is a direct link between the level of information disclosure and market efficiency.

The aim of this article is to estimate the level of compliance with information disclosure requirements under IFRS 3 Business Combinations as demonstrated by companies listed on Prague Stock Exchange (PSE), to establish the determinants of non-compliance and importance of company-specific factors.

The analysis identifies the degree of disclosure and factors that influence the level of compliance with disclosure standards. The research is based on publicly available company annual reports.

In order to examine the impact of potentially decisive factors that might determine the level of IFRS 3 compliance in reporting of business combinations, I have analysed the relative link between the estimated degree of compliance with disclosure requirements and:

- number of years of trading at Prague Stock Exchange,

- company size,

- ownership structure (concentrated vs. dispersed),

- estimated price of the business combination.

By assessing the compliance with information disclosure requirements under IFRS 3 in companies listed on PSE, this study aims to provide a high-level understanding of the quality of reports that minority investors and the general public can work with, and to identify whether there is a need for regulatory intervention. Through introduction of the impact factors analysis, the research goes one level deeper into determining what company-specific characteristics have a positive influence on compliance with disclosure requirements. 


\section{Literature Review}

A financial statement is key information channel mediating relations between a company and its stakeholders. Disclosure of information thus influences behaviour of investors and impacts their decision on whether to hold or sell their shares or whether any changes in management of the given company are necessary. The typology includes mandatory (required by law or accounting standards) and voluntary disclosure. Voluntary disclosures are not specifically required by laws, but nevertheless provide an important context to the financial data.

The literature review focuses on general influence of disclosure in financial statements on the capital markets and companies themselves, followed by a discussion of specific aspects of disclosure in business combinations. Furthermore, the literature review covers research conducted on Czech companies and links the uncovered findings to the specific factors that are believed to impact the level of compliance with disclosure standards.

Two landmark studies by Myers and Majluf (1984) and Greenwald et al. (1984) conclude that information asymmetry often causes companies to give up positive net present value projects in the light of high requirements of external financing providers. Low level of information disclosure leads to situations where the company management has all the data necessary to value the company's assets and shares, whereas the external equity providers do not have data to adequately value the company. The mispricing by capital market participants and the unwillingness of shareholders to issue undervalued shares lead to passing on projects with promising net present values and subsequent underinvestment of the company.

In Holland's (1998) work on financial reporting and private disclosure it is argued that the main goal of company's disclosure actions is to provide the necessary context for investors and other stakeholders to interpret the firm's information adequately and in a similar manner to ensure proper valuation of its shares.

Hope et al. (2006) found that countries with weaker investor protection mechanisms are more likely to adopt IFRS and put emphasis on disclosure and thus concluded that IFRS represent a vehicle through which countries can improve the investor protection and make their capital markets more accessible to foreign investors.

$\mathrm{Lu}$ (2014) goes deeper into the research of disclosure of non-financial information in financial statements and reports and examines how it helps to mitigate the underinvestment problem. The analysed sample included 216 US electronic equipment firms (a single industry was chosen to insure comparability of nonfinancial disclosure across companies). This research concludes that firms 
providing more non-financial information are less likely to underinvest, and that non-financial disclosure is positively associated with the subsequent equity financing (as compared to debt).

The non-financial context is especially important in disclosing data on business combinations, because of their strong strategic implications for the future development of the given company. They also influence the creation of certain expectations in the capital market. These are usually transactions of a larger magnitude which significantly impact not only financial statements of the given year, but also the financial results in subsequent periods.

IFRS are not the dominant reporting system of the Czech Republic. The first group of Czech IFRS adopters comprised publicly listed companies which are required by the Section 4 of the EU Directive No. 1606/2002 ${ }^{1}$ to prepare their accounts consolidation in accordance with IFRS. Numerous firms have voluntarily adopted IFRS due to the fact that they are a part of an international corporate group and/or a subsidiary of a foreign company. In this case, the adoption is directed internally for the benefit of the group consolidation. It was legally allowed by amendment of the Law on Accounting in 2011. Apart from the described cases, the law allows any consolidating entity to voluntarily implement IFRS (Procházka, 2016).

Ramanna and Sletten (2009) have argued that the spread of IFRS can be attributed to the network effect, meaning that the firms in economies where local accounting standards are prevalent are more likely to adopt IFRS when their trade and strategic partners are companies reporting in accordance with IFRS. Besides the legal requirement applicable to the publicly listed companies, this might be the strongest motivation for Czech firms to run two separate accounting reporting systems (under the Czech GAAP and IFRS).

Several recent pieces of research were dedicated to the empirical analysis of compliance of Czech companies with different IFRS disclosure requirements. Those more recent are mentioned below. The uniform conclusion is that the level of compliance is at the minimum required level with most common deficiencies in aspects regarding voluntary disclosure, disclosure of methods and approaches and qualitative/descriptive data disclosure.

Quality of information disclosed in annual reports of the listed companies in the Czech Republic was analysed by Čevela (2016) The objective of his research was to identify the level of information disclosure across several types of annual reports and a total of 40 requirements. It has been found that the main obligations towards the investors are met. Disclosures often miss some formal aspects, but are

1 Regulation (EC) No 1606/2002 of the European Parliament and of the Council of 19 July 2002 on the application of international accounting standards. 
factual in nature and more deficiencies were found in foreign companies audited by foreign auditors. The highest level of disclosure was maintained in profit and loss accounts, while disclosure of the relevant aspects in the Report on relations and the Report of the Board of Directors was less satisfactory.

According to Knorová (2016) who analysed disclosure of revenues in accordance with IAS 18 and IFRS 15, the standards were met, but there was a high degree of variability between companies in terms of information provided beyond the mandatory minimum. The reports of analysed companies significantly varied in the level of revenues' structural analysis and details of revenues recognition methodology provided.

Boučková (2016) and the more recent study by Novák (2018) both found that the required level of goodwill disclosure is not met by Czech publicly listed companies.

The paper by Kopecká (2016) deals with the level of disclosure realised by ten selected Czech publicly listed companies (the sample was designed to cover various industries) in accordance with IFRS 8, which requires that details about companies operations are disclosed, in particular: product and services segments, geographical area of operations, target customers, etc. The premise is that these disclosures serve to investors as a basis for predicting the entity's growth. On a sample of data from 2013, Kopecká has found that the level of compliance was fairly low and especially voluntary disclosures were kept at the minimal level.

In the same light, the paper by Dvořák (2017) has found that the level of compliance with IFRS 13, which covers fair value management, was low especially with regard to the valuation techniques and inputs.

The only research on compliance of PSE listed companies with disclosure requirements under IFRS 3 was conducted by Pospíšil (2017). The author has analysed annual reports for the period 2011-2014 and found a significant variability in the estimated level of compliance (from $47 \%$ to $86 \%$ ), generally concluding that the level was insufficient. In the presented paper, I extend the estimated period to 5 years using the more recent data (2012-2016) and compared to Pospíśil measure the weighted level of compliance in order to reflect the different significance of disclosure requirements and their cost. The contribution of this paper is also the fact that I build on my findings by going further and analysing what are the factors that impact company willingness or capacity to disclose information on business combinations.

\subsection{Impact factors}

Generally the quality of financial reports and accounting data depends on the quality and level of detail of the accounting standards applied, as well as the 
measure to which the compliance is enforced or motivated. This study deals with the second aspect and while it does not dive deep into the quality of particular standards, my research rather examines how and why they are applied.

Albeit many studies attribute the IFRS adoption and compliance to internal motivation of the management, IFRS implementation in the Czech Republic has due to the specifics of the Czech financial system and capital market in most cases taken place either in order to comply with the law or with policies of a foreign/international governing corporate body. In both cases, the adoption is involuntary, so the "internal motivation" factor does not seem to be in place.

When researching the studies dedicated to the analysis of the factors influencing the quality of IFRS reporting, several aspects have been mentioned and tested by the scholars. These are primarily the size of the company, auditor type, ownership structure, and profitability.

Researchers support the idea that larger companies have higher compliance level with disclosure requirements and attribute this effect to the motivation of protecting the firm's reputation, avoiding governmental interventions by being voluntarily transparent and minimising agency costs. The latter occurs due to complicated internal structuring of such companies and multi-layered management (Dumontier and Raffournier, 1998; Demir and Bahadir, 2014).

It is argued that the type of external auditor hired by the firm significantly influences the level of compliance with IFRS. Large and renowned auditors serve as monitoring bodies and exert more pressure on the management to follow the standards of disclosure (Street and Bryant, 2000).

Higher level of disclosure has been reported in more profitable companies as it is in line with the company desire to signal the strength to its shareholders and the capital market in general. Managers are also motivated to demonstrate their successes (Demir and Bahadir, 2014).

In case of a dispersed ownership structure, minority shareholders might experience agency problems as they have little power to demand information from the management upon request. To tackle this problem, companies with dispersed ownership disclose more information. However, this works only when shareholders enjoy a strong legal protection in certain jurisdictions. Otherwise, dominant owners are not motivated to keep high level of disclosure (Leuz and Wysocki, 2016).

\subsection{Costs and benefits of compliance with disclosure requirements}

Researchers have analysed the motivation for IFRS adoption with an ultimate goal of finding the best way to promote their voluntary implementation. Motivation is 
certainly driven from the benefits arising from compliance with international accounting standards.

Hope et al. (2006) argue that institutional factors on the level of whole jurisdictions are just as important as the incentive of international harmonisation or individual firm interests. Key institutional incentive is to strengthen investor protection mechanism and boost capital market's development. Thus, the countries with low level of national protection of investors and disclosure requirements opt for supporting the implementation of IFRS.

There is however a direct impact of due reporting on companies' financial performance, which can be a strong motivational benefit. In their study of economic consequences of increased disclosure, Leuz and Verrecchia demonstrated that lower information asymmetry achieved by commitment to higher level of disclosure decreases the cost of capital by boosting the volumes of trading shares, narrowing bid-ask price spreads and contributing to the more stable share price development (Leuz and Verrecchia, 2000). Voluntarily disclosures and rigorous compliance with IAS reduces information asymmetry, which leads to decrease in agency costs for the shareholders. This is another factor reducing companies' cost of equity (Kothari, 2000).

Appropriate disclosure level results into a better understanding and comparability of investment opportunities and thus more effective capital allocation, which manifests itself in reduced cost of equity (Kothari, 2000).

These conclusions have been supported by research of Danske et al. (2008) who tested the economic impact of mandatory IFRS adoption on the example of 26 countries (mainly European). Results showed that first-time IFRS implementation contributed to the increase in market liquidity and share valuations. The evidence also supported the fact that cost of capital decreased due to the higher level of disclosure. The effects were more prominent in countries were IAS were strictly enforced.

Another aspect in which firms can benefit from a higher level of disclosure is the liquidity of shares, which translates into ability to satisfy short-term obligations in case they fall due (Cascino and Gassen, 2015).

Costs of disclosure as compared to the associated benefits are easier to identify (in some cases even easier to quantify), so when the benefits are not obvious to the management, extending the range of disclosure seems like a losing game. These costs include direct expenses related to administrative and accounting work (staff hours, experts, advisers, software, etc.). When considering the sensitivity and proprietary character of information to be disclosed, the company might potentially encounter indirect costs of inquiries from shareholders, litigations, or 
Nistorenco, T.: Compliance with Disclosure Requirements under IFRS 3 of Companies Trading at Prague Stock Exchange

involuntary disclosure of a particular firm strategy comprised in realisation of a business combination (Kothari, 2000).

\section{Data and Methodology}

Data research was conducted on a sample of 23 companies; all entities are trading at Prague Stock Exchange on the Prime or Standard Market. The majority of the companies are Czech stock companies with either local or international brand. The companies are a part of the PX index.

The compliance with information disclosure requirements set in IFRS 3 was examined based on the data made public in annual reports available to the shareholders for the period of five years (2012-2016). The total number of selected annual reports is 115 . Central European media enterprises were excluded from the sample due to their compliance with US GAAP accounting standards.

From the total number of companies, 14 firms have acquired businesses in the period 2012-2016. These companies have realised 43 business combinations that fall subject to IFRS 3 (the assets acquired and liabilities assumed constitute a business). It is important to mention that mergers, demergers, sales of assets, joint ventures, combinations of entities or businesses under common control are not subject to IFRS 3 disclosure requirements. Thus, numerous acquisitions made by VGP NV, a company operating in real estate and industrial sites construction, were not included in the selected transactions due to the fact that they had acharacter of assets acquisition.

Fig. 1 Sample data in numbers

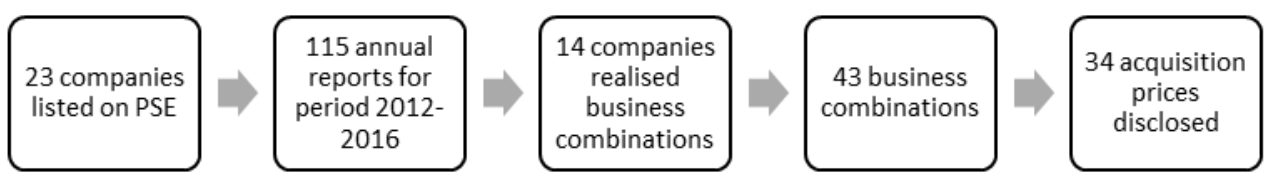

Source: own calculations.

The companies presented in the sample have different business profiles and there is no dominant industry presented. The most represented were financial and energy sectors followed by beverages production. 
Tab. 1 Companies in the analysed sample

\begin{tabular}{|c|c|c|}
\hline Company & Year of entrance to PSE & Industry \\
\hline ČEZ, a. s & 1993 & energy \\
\hline Fortuna Entertainment Group N.V. & 2010 & entertainment/gambling \\
\hline Kofola ČeskoSlovensko a.s. & 2015 & non-alcoholic beverages \\
\hline UNIPETROL, a.s. & 1997 & energy (fuel) \\
\hline TOMA, a.s. & 1995 & non-alcoholic beverages \\
\hline STOCK SPIRITS GROUP PLC & 2013 & alcoholic beverages \\
\hline ENERGOAQUA, a.s. & 1993 & energy \\
\hline Komerění banka a.s. & 1995 & banking \\
\hline O2 Czech Republic & 1995 & telecommunications \\
\hline New World Resources & 2011 & energy (coal extraction) \\
\hline VIG & 2008 & insurance \\
\hline Tatry Mountain Resorts a.s. & 2012 & leisure \\
\hline RMS Mezzanine, a.s. & 1993 & investment management \\
\hline Erste Group Bank AG & 2002 & banking \\
\hline MONETA Money Bank, a.s. & 2016 & banking \\
\hline PEGAS NONWOVENS S.A & 2006 & technical textiles \\
\hline E4U a.s & 2011 & energy \\
\hline Jáchymov Property Management, a.s. & 1993 & property management \\
\hline Philip Morris ČR a.s. & 1993 & tobacco products \\
\hline Pražské služby a.s. & 1995 & public services \\
\hline $\begin{array}{l}\text { CENTRAL } \quad \text { EUROPEAN } \\
\text { ENTERPRISES LTD. }\end{array}$ & 2005 & media \\
\hline VGP NV & 2007 & $\begin{array}{l}\text { logistics and semi- } \\
\text { industrial real estate }\end{array}$ \\
\hline
\end{tabular}

Source: PSE, companies' webpages.

Each annual report was examined with respect to compliance with the disclosure requirements set by IFRS 3, mainly whether the requirements are met from the qualitative (with explanations and descriptions) and quantitative (amounts, financial impacts) point of view. The level of compliance with any particular clause in disclosure requirements was graded from 0 to $100 \%$, in case the requirement was not applicable in a particular case, the point was graded , $\mathrm{x}$ “ and excluded from calculations. Each requirement had a weight (points from 1 to 3) set by the author (see Annex 1). The more complex and detailed the requirement, the more points it is given due to the fact that the basic ones (like identification of acquiree, date of acquisition, percentage of equity acquired) are automatically expected to be disclosed. At the same time, requirements in the field of contingent liabilities, gains or losses from transaction, immaterial business combinations that are material collectively, details for transactions recognised separately, tax 
deductible goodwill, and qualitative description of factors that make the goodwill recognised have higher disclosure costs. Even though this method of attributing weights to each requirement is subjective, the aim was to "highlight" the fulfilment of the most time and data-demanding disclosure requirements.

The total number of points for compliance with each disclosure requirement was calculated as a grade (value from 0 to $100 \%$ ) multiplied by a weight (points from one to three). The final level of compliance was thus computed as a weighted average, where the sum of total points was different in every case since some requirements were not applicable in particular cases. The resulting level of compliance expressed in percent is shown in the table below.

Tab. 2 Assessed level of compliance with information disclosure requirements under IFRS 3 in companies listed on PSE

\begin{tabular}{lccccc}
\hline Company / level of compliance ( in \%) & $\mathbf{2 0 1 2}$ & $\mathbf{2 0 1 3}$ & $\mathbf{2 0 1 4}$ & $\mathbf{2 0 1 5}$ & $\mathbf{2 0 1 6}$ \\
\hline ČEZ, a. s & 63 & 65 & 65 & 63 & 58 \\
Fortuna Entertainment Group N.V. & 38 & - & 34 & - & 38 \\
Kofola ČeskoSlovensko a.s. & - & - & - & 64 & 71 \\
UNIPETROL, a.s. & 50 & 50 & 60 & 42 & 52 \\
TOMA, a.s. & 22 & - & - & 69 & 36 \\
STOCK SPIRITS GROUP PLC & 50 & - & - & - & 41 \\
ENERGOAQUA, a.s. & - & - & - & 33 & - \\
Komerční banka a.s. & - & - & 68 & - & 69 \\
O2 Czech Republic & 65 & - & 70 & - & - \\
New World Resources & 55 & 50 & 55 & - & - \\
VIG & - & 67 & 75 & - & - \\
Tatry Mountain Resorts a.s. & - & 60 & 60 & 60 & - \\
RMS Mezzanine, a.s. & 24 & - & - & - & - \\
Erste Group Bank AG & - & - & - & - & - \\
MONETA Money Bank, a.s. & - & - & - & - & - \\
PEGAS NONWOVENS S.A & - & - & - & - & - \\
E4U a.s & - & - & - & - & - \\
Jáchymov Property Management, a.s. & - & - & - & - & - \\
Philip Morris ČR a.s. & - & - & - & - & - \\
Pražské služby a.s. & - & - & - & - & - \\
\hline
\end{tabular}

Source: Sample companies' annual reports, own calculations.

Before we move to the analysis of links between different characteristics of the sample companies and the assessed level of compliance, it is necessary to discuss the limitation of further analysis and the dark spots in the estimations conducted.

First of all, a significant disclaimer is the fact that IFRS do not require to specify whether each standard is applicable in the particular case/year. This creates 
a situation when the researcher cannot be sure that a certain disclosure was not made because the relevant event did not take place or simply because the requirement was omitted. Based on the "presumption of innocence" I considered that in cases when there were neither explicit nor implicit mentioning of a certain event (e.g. when occurrence of an event is evident from the specific accounting operations), there is no substantial basis for assuming that it could have happened.

Secondly, the limited number of publicly listed companies in the Czech Republic and their rather modest M\&A activity compromises the ability to make any general statements. Nevertheless, the analysed sample over five years includes 34 incidents of business combinations. This number is considered acceptable for deriving comprehensive regression models.

The results of the literature review summarised above and the author's own assumptions were used to formulate the following hypothesis:

1. H1 - level of compliance is higher in large companies. This link is based on the assumption that large firms are capable to provide necessary budget, staff and technology to keep accounting in two versions (CAS and IFRS). Corporations are also complex structures, so effective reporting (including disclosures) is crucial for their management of processes across the divisions or departments. The proxy for company's size is its annual revenues.

2. H2 - level of compliance is higher in companies with dispersed ownership structure. The premise of this assumption implies that in case of a larger number of shareholders, the significance of disclosing realised business combinations is higher. It is fair to suppose that in case of numerous minority owners, the pressure to comply with disclosure requirements can be driven by establishing a trustworthy environment that is crucial for share price growth.

3. H3 - the higher the number of years trading at PSE, the higher the level of compliance with disclosure requirements. In this hypothesis, I work with the assumption that history of being traded at PSE equals to experience with IFRS and thus means higher level of compliance.

4. $\mathrm{H} 4$ - in cases of high acquisition expenses the level of compliance with disclosure requirements is higher. This implies that larger business combinations are analysed in more detail and thus there is more information to disclose. 
Nistorenco, T.: Compliance with Disclosure Requirements under IFRS 3 of Companies Trading at Prague Stock Exchange

The following variables where considered but ultimately dismissed due to the following reasons:

- auditor - majority of the companies in the sample were audited by a Big4 company, so there was not enough differentiation to analyse,

- industry differentiation has not been analysed for the reason of too many variables per small sample (financial vs. non-financial division could have been done, but again considering that only four companies would fall into the category Financial, the validity of outputs of the regression model would be questionable).

- indebtedness as a proxy for reporting incentives of management to disclose all relevant information did not seem relevant due to the fact of how accessible the debt financing was within the analysed period in the Czech Republic.

Generally I have tried to test the factors that could be attributed to the most companies in the sample.

To test the above hypothesis regression model was built with the use of Eviews programme.

The first model was based on the dependent variable LEVEL OF COMPLIANCE, descriptive variables COMPANY SIZE, OWNERSHIP STRUCTURE, YEARS TRADING ON PSE and a constant. The variable ACQUISITION PRICE (which represents total estimated acquisition expenses of a company in a certain year) was not included in this model due to the missing values in several cases. To analyse the link between the level of compliance and total acquisition expenses, a separate model was built.

The variables had the following characteristics:

Tab. 3 Descriptive statistics of the model's variables

\begin{tabular}{llllll}
\hline Variable & Units & Average & Median & Max & Min \\
\hline LEVEL OF COMPLIANCE & $\%$ & $54 \%$ & $59 \%$ & $75 \%$ & $22 \%$ \\
COMPANY SIZE & mil CZK & 76,785 & 25,951 & 318,000 & 63 \\
YEARS TRADING ON PSE & years & 13.9 & 19 & 23 & 1 \\
ACQUISITION PRICE & mil CZK & 576.5 & 148.9 & 4,132 & 0.24 \\
\hline
\end{tabular}

Source: Sample companies' annual reports, own calculations.

OWNERSHIP STRUCTURE - this variable had two categories: dispersed and concentrated ownership.

The first model output is shown in the table below. Because of the magnitude of differences between sample data, a log of the variable is used for the model. Ttest demonstrates that the constant and explanatory variables YEARS TRADING 
ON PSE and COMPANY SIZE are statistically significant at the $10 \%$ level of significance. F-test proves the statistical significance of the entire model. The coefficient of determination is relatively low, but it has a positive value. Based on ARCH test, no heteroscedasticity was found (residues have similar variance). The value of Durbin-Watson test is close to 2, which proves that there is no autocorrelation between the residues of variables in the model.

Fig. 2 Logarithmic regression model (three variables) - results

\begin{tabular}{|c|c|c|c|c|}
\hline \multicolumn{5}{|c|}{$\begin{array}{l}\text { Dependent Variable: LOG_LEVEL } \\
\text { Method: Least Squares } \\
\text { Date: } 07 / 05 / 18 \text { Time: } 16: 26 \\
\text { Sample: } 134 \\
\text { Included observations: } 34\end{array}$} \\
\hline Variable & Coefficient & Std. Error & $\mathrm{t}$-Statistic & Prob. \\
\hline $\begin{array}{c}\text { C } \\
\text { YEARS_TRADING_ON_PSE } \\
\text { OWNERSHIP_STRUCTURE } \\
\text { COMPANY_SIZE }\end{array}$ & $\begin{array}{r}-0.564269 \\
-0.010725 \\
-0.128893 \\
1.73 E-06\end{array}$ & $\begin{array}{r}0.104123 \\
0.006129 \\
0.097793 \\
5.13 E-07\end{array}$ & $\begin{array}{r}-5.419274 \\
-1.749845 \\
-1.318010 \\
3.374604\end{array}$ & $\begin{array}{l}0.0000 \\
0.0904 \\
0.1975 \\
0.0021\end{array}$ \\
\hline $\begin{array}{l}\text { R-squared } \\
\text { Adjusted R-squared } \\
\text { S.E. of regression } \\
\text { Sum squared resid } \\
\text { Log likelihood } \\
\text { F-statistic } \\
\text { Prob(F-statistic) }\end{array}$ & $\begin{array}{r}0.286902 \\
0.215592 \\
0.274706 \\
2.263906 \\
-2.186339 \\
4.023316 \\
0.016136\end{array}$ & \multicolumn{2}{|c|}{$\begin{array}{l}\text { Mean dependent var } \\
\text { S.D. dependent var } \\
\text { Akaike info criterion } \\
\text { Schwarz criterion } \\
\text { Hannan-Quinn criter. } \\
\text { Durbin-Watson stat }\end{array}$} & $\begin{array}{r}-0.655933 \\
0.310168 \\
0.363902 \\
0.543474 \\
0.425141 \\
1.883921\end{array}$ \\
\hline
\end{tabular}

Source: Eviews programme, own calculations.

Regression model shows that the level of compliance with information disclosure requirements under IFRS might be determined by the size of the company and the period of trading at PSE. The ownership structure is not statistically linked to the level of compliance; it is visible with a bare eye that some low-level compliance results have occurred in companies with both concentrated and dispersed ownership. The hypothesis that the level of compliance is higher in companies with dispersed ownership was not proved on the presented sample of data.

A separate model testing the statistical links between the acquisition price paid for a business combination and the level of compliance did not prove the initial hypothesis that in the case of large acquisitions, the companies perform a more thorough disclosure of information. The results imply that the size of the deal does not significantly motivate reporting teams to pay special attention to disclosure requirements. 
Nistorenco, T.: Compliance with Disclosure Requirements under IFRS 3 of Companies Trading at Prague Stock Exchange

Fig. 3 Linear regression model (Acquisition Price variable) - results

\begin{tabular}{|c|c|c|c|c|}
\hline \multicolumn{5}{|c|}{$\begin{array}{l}\text { Dependent Variable: LEVEL_OF_COMPLIANCE } \\
\text { Method: Least Squares } \\
\text { Date: } 07 / 05 / 18 \text { Time: } 16: 39 \\
\text { Sample: } 122 \\
\text { Included observations: } 22\end{array}$} \\
\hline Variable & Coefficient & Std. Error & t-Statistic & Prob. \\
\hline$\frac{\text { C }}{\text { ACQUISITION_PRICE }}$ & $\begin{array}{l}0.516130 \\
4.54 \mathrm{E}-05\end{array}$ & $\begin{array}{l}0.033436 \\
2.93 E-05\end{array}$ & $\begin{array}{l}15.43641 \\
1.549287\end{array}$ & $\begin{array}{l}0.0000 \\
0.1370\end{array}$ \\
\hline $\begin{array}{l}\text { R-squared } \\
\text { Adjusted R-squared } \\
\text { S.E. of regression } \\
\text { Sum squared resid } \\
\text { Log likelihood } \\
\text { F-statistic } \\
\text { Prob(F-statistic) }\end{array}$ & $\begin{array}{l}0.107154 \\
0.062512 \\
0.135303 \\
0.366136 \\
13.83708 \\
2.400291 \\
0.136992\end{array}$ & \multicolumn{2}{|c|}{$\begin{array}{l}\text { Mean dependent var } \\
\text { S.D. dependent var } \\
\text { Akaike info criterion } \\
\text { Schwarz criterion } \\
\text { Hannan-Quinn criter. } \\
\text { Durbin-Watson stat }\end{array}$} & $\begin{array}{r}0.542323 \\
0.139741 \\
-1.076098 \\
-0.976913 \\
-1.052733 \\
2.420852\end{array}$ \\
\hline
\end{tabular}

Source: Eviews programme, own calculations.

\section{Results and Discussion}

Logarithmic regression model mapped the relations between determined companyspecific factors with potential impact on the level of compliance with disclosure requirements. These factors were: years trading on PSE as a proxy for experience in dealing with IFRS; ownership structure as a proxy for shareholders interest in complying with disclosure requirements; company size as a proxy for available staff and accounting infrastructure to facilitate IFRS implementation, and compliance and as a proxy for organisational complexity and relative market position.

On the $10 \%$ level of significance, the regression has proved that there is a causal link between the company size and its level of compliance with IFRS disclosure requirements in support of Hypothesis 1. Evidently large corporations deal better with the challenges of keeping double accounting (CAS and IFRS), managing extensive reporting process and providing the external and internal users with sufficient details regarding acquisition activity. The size of the company also relates to its market position and top-players tend to be diligent and transparent with their reporting practices. 
A certain level of dependence in this particular sample of cases has been detected between the level of disclosure compliance and the number of years of trading on PSE (Hypothesis 3). As mentioned above, the hypothesis suggested that longer history of PSE listing, which is the ultimate factor that obliges the companies to implement IFRS and be especially diligent and mindful about disclosing their M\&A activity to the investors and general public, positively influences the level of compliance with disclosure requirements under IFRS 3. Nevertheless, the coefficient of the regression model suggests the opposite.

I believe the result was distorted by the case of Kofola, a company with consistently one of the highest disclosure compliance, but a short history of trading at PSE. Also, the assumption of PSE history being equal to IFRS experience does not hold in all the cases: e.g. Stock Spirits Group is on PSE since 2013, but had previous experience with IFRS; Toma is on PSE since 1995, but did not perform well in terms of the compliance level, etc.

More plausible is the explanation that apart mere experience with IFRS accounting, important is also the level of significance and value added to the company and its stakeholders that comes from complying with disclosure requirements. It is fair to say that with listing on the stock exchange, the value of transparency and information availability becomes higher and contributes to the liquidity of shares and higher trading volumes.

The level of ownership dispersion has not proved to be a significant impact factor with regard to compliance with disclosure requirements despite initial assumption and the insight from the literature overview (Hypothesis 2). This can be attributed to the low level of investors' protection in the Czech Republic. Thus, having a large number of minority shareholders does not encourage managers to disclose more information.

Business combination aspect has also failed to rank among defining parameters for the level of disclosure (Hypothesis 4). The reasoning behind this finding may lie in the fact that larger acquisitions are often of a strategic nature and the companies are cautious to disclosure any further details not to compromise their strategic move.

\section{Conclusion}

The research conducted on the sample of 115 annual reports of companies listed on Prague Stock Exchange has revealed significant non-compliance with information disclosure requirements under IFRS 3. The maximum estimated level of compliance is $75 \%$, even though most of the companies oscillated around 50\% compliance level. 
It can be argued that these findings are the result of low enforcement of IFRS compliance as well as a relatively low level of investor protection in the Czech Republic. Another explanation is the fact that the costs of disclosure are more evident to the management as they have a more direct character, while benefits manifest themselves indirectly and with a significant time delay.

Due to the sensitivity of data related to business combinations that companies are required to make public, even in cases where disclosure is made, the least revealing format of information display is chosen by the management. We cannot disregard the factor of unintentional neglect, misinterpretation of IFRS requirement, or simply lack of competences and experience in working with IFRS.

The analysis of company-specific factors with a potential impact on the level of compliance with the disclosure requirement under IFRS 3 has demonstrated that larger companies have higher levels of compliance. Sufficient infrastructure and resources as well as internal motivation of large and more complex corporations to comply with IFRS 3 also play an important role in their diligent implementation.

In some particular cases, longer history of the listing status contributes to the company's proficiency in working with IFRS 3 and motivates the disclosure as companies with longer experience of trading might have already become aware of the benefits which transparency brings for listed businesses.

Taking into consideration results of the literature review with respect to the level of compliance with different IFRS 3 disclosure requirement, it can be stated that the results of this research stay in line with the findings of the cited literature and highlight a non-satisfactory level of compliance. 


\section{References}

Boučková, M. 2016. Quality of Disclosed Information with Emphasis on Goodwill Impairment. European Financial and Accounting Journal 2, 37-52. DOI: $10.18267 /$ j.efaj. 156 .

Cascino, S., Gassen, J. 2015. What drives the comparability effect of mandatory IFRS adoption? Review of Accounting Studies, 20 (1). pp. 242-282. ISSN 13806653. Available from: <papers.ssrn.com/sol3/papers.cfm3abstract_id=1402206>. [30 July 2019].

Čevela, D. 2016. Quality of Information Disclosed in Annual Reports of Listed Companies in the Czech Republic. European Financial and Accounting Journal 2, 21-36. DOI: 10.18267/j.efaj.155.

Daske, H., Hail, L., Leuz, C., Verdi, R. 2008. Mandatory IFRS Reporting around the World: Early Evidence on the Economic Consequences. Journal of Accounting Research, 2008, vol. 46, issue 5, 1085-1142. DOI: $\underline{10.1111 / \mathrm{j} .1475-}$ 679X.2008.00306.x.

Demir, V., Bahadir, O. 2014. An Investigation of Compliance with International Financial Reporting Standards by Listed Companies in Turkey. Accounting and Management Information Systems. Available from: < researchgate.net/publication/317068381_An_investigation_of_compliance_with_I nternational_Financial_Reporting_Standards_by_listed_companies_in_Turkey>. [30 July 2019].

Dumontier, P., Raffournier, B. 1998. Why Firms Comply Voluntarily with IAS: an Empirical Analysis with Swiss Data. Journal of International Financial Management \& Accounting Volume 9:216-245. DOI: 10.1111/1467-646X.00038.

Dvořák, J. 2017. How Do Czech Companies Report Fair Value Measurement Under IFRS 13? European Financial and Accounting Journal 2017/3. DOI: 10.18267/j.efaj.191.

Greenwald, B. C., Stiglitz, J. E., Weiss, A. 1984. Informational Imperfections in the Capital Markets and Macro-economic Fluctuations. American Economic Review 74.2:194-199. DOI: 10.3386/w1335.

Holland, J. 1998. Financial Reporting, Private Disclosure and the Corporate Governance Role of Financial Institutions. Journal of Management \& Governance, 3(2), 161-187. DOI: 10.1023/A:1009991609633.

Hope, O. K., Jin, J. Y., Kang, T. 2006. Empirical Evidence on Jurisdictions that Adopt IFRS. Journal of International Accounting Research: Fall, Vol. 5, No. 2, pp. 1-20. DOI: $10.2139 / \mathrm{ssrn} .751264$. 
Nistorenco, T.: Compliance with Disclosure Requirements under IFRS 3 of Companies Trading at Prague Stock Exchange

Jaggi, B., Low, P. Y. 2000. Impact of culture, market forces and legal system on financial disclosures. The International Journal of Accounting, Vol. 35, No. 4, 495-519. DOI: 10.1016/s0020-7063(00)00076-5.

Knorová, K. 2016. Do Czech Companies Disclose Revenue in Accordance with IFRS Requirements? European Financial and Accounting Journal 3, 69-84. DOI: 10.18267/j.efaj.163.

Kopecká, N., 2016. The IFRS 8 Segment Reporting Disclosure: Evidence on the Czech Listed Companies. European Financial and Accounting Journal 2, 5-20. DOI: $10.18267 /$ j.efaj.154.

Kothari, S. P. 2000. The role of financial reporting in reducing financial risks in the market. Conference series, Federal Reserve Bank of Boston, vol. 44, 89-112. Available from: <bostonfed.org/-/media/Documents/conference/44/cf44_6.pdf>. [30 July 2019].

Leuz, C., Verrecchia, R. 2000. The Economic Consequences of Increased Disclosure. Journal of Accounting Research, 38, 91-124. DOI: 10.2307/2672910.

Leuz, C., Wysocki, P. 2016. The Economics of Disclosure and Financial Reporting Regulation: Evidence and Suggestions for Future Research. Journal of Accounting Research, Vol. 54, No. 2, 525- 622. DOI: 10.1111/1475-679x.12115.

Lu, H.-Y. 2014. Does Disclosure of Non- Financial Statement Information Reduce Firms' Propensity to Under-Invest? SSRN Electronic Journal, DOI: 10.2139/ssrn.1465096.

Myers, S. C., Majluf, N. S. 1984. Corporate Financing and Investment Decisions When Firms Have Information That Investors Do Not. Journal of Financial Economics 13.2, 1984: 187-221. Available from: 〈nber.org/papers/w1396.pdf〉. [30 July 2019].

Novák, M. 2018. The Quality of Disclosure under IAS 38 in Financial Statements of Entities Listed on PSE. European Financial and Accounting Journal 2018/2. DOI: 10.18267/j.efaj.208.

Pospíšil, J. 2017. IFRS 3 Compliance Research at Czech Capital Market. Acta academica karviniensia, 76-86. Available from: <aak.cms.opf.slu.cz/pdf/2017/ 1/Pospisil.pdf>. [30 July 2019].

Procházka, D. 2016. Vynucené přijetí IFRS českými nekótovanými podniky: hodnocení prínosů a nákladů. Acta Oeconomica Pragensia DOI: 10.18267/j.aop.528. 
Ramanna, K., Sletten, E. 2009. Why do Countries Adopt International Financial Reporting Standards? Harvard Business School Accounting \& Management Unit Working Paper No. 09-102. DOI: 10.2139/ssrn.1460763.

Street, D. L., Bryant, S. M. 2000. Disclosure level and compliance with IASs: A comparison of companies with and without U.S. listings and filings. The International Journal of Accounting, 35(3), 305-329. DOI: 10.1016/S00207063(00)00060-1.

Prague Stock Exchange. 2018. Available from: <pse.cz/udaje-o-trhu/akcie>. [30 July 2019]. 


\section{Annex 1 Disclosure requirements under IFRS 3 and the weight appointed to each requirement}

\begin{tabular}{|c|c|}
\hline Disclosure requirement under IFRS 3 & Weight \\
\hline the name and a description of the acquiree. & 1 \\
\hline the acquisition date. & 1 \\
\hline the percentage of voting equity interests acquired. & 1 \\
\hline $\begin{array}{l}\text { the primary reasons for the business combination and a description of how the acquirer obtained } \\
\text { control of the acquiree. }\end{array}$ & 1 \\
\hline $\begin{array}{l}\text { a qualitative description of the factors that make up the goodwill recognised, such as expected } \\
\text { synergies from combining operations of the acquiree and the acquirer, intangible assets that do not } \\
\text { qualify for separate recognition or other factors. }\end{array}$ & 2 \\
\hline $\begin{array}{l}\text { the acquisition-date fair value of the total consideration transferred and the acquisition-date fair value } \\
\text { of each major class of consideration, such as: (i) cash; (ii) other tangible or intangible assets, including } \\
\text { a business or subsidiary of the acquirer; (iii) liabilities incurred, for example, a liability for contingent } \\
\text { consideration; and (iv) equity interests of the acquirer, including the number of instruments or } \\
\text { interests issued or issuable and the method of determining the fair value of those instruments or } \\
\text { interests. }\end{array}$ & 1 \\
\hline $\begin{array}{l}\text { for contingent consideration arrangements and indemnification assets: (i) the amount recognised as of } \\
\text { the acquisition date; (ii) a description of the arrangement and the basis for determining the amount of } \\
\text { the payment; and (iii) an estimate of the range of outcomes (undiscounted) or, if a range cannot be } \\
\text { estimated, that fact and the reasons why a range cannot be estimated. If the maximum amount of the } \\
\text { payment is unlimited, the acquirer shall disclose that fact. }\end{array}$ & 1 \\
\hline $\begin{array}{l}\text { for acquired receivables: (i) the fair value of the receivables; (ii) the gross contractual amounts } \\
\text { receivable; and (iii) the best estimate at the acquisition date of the contractual cash flows not expected } \\
\text { to be collected. The disclosures shall be provided by major class of receivable, such as loans, direct } \\
\text { finance leases and any other class of receivables. }\end{array}$ & 1 \\
\hline $\begin{array}{l}\text { i. the amounts recognised as of the acquisition date for each major class of assets acquired and } \\
\text { liabilities assumed. }\end{array}$ & 1 \\
\hline $\begin{array}{l}\text { j. for each contingent liability recognised in accordance with paragraph } 23 \text {, the information required in } \\
\text { paragraph } 85 \text { of IAS } 37 \text { Provisions, Contingent Liabilities and Contingent Assets. If a contingent } \\
\text { liability is not recognised because its fair value cannot be measured reliably, the acquirer shall } \\
\text { disclose: (i) the information required by paragraph } 86 \text { of IAS 37; and (ii) the reasons why the liability } \\
\text { cannot be measured reliably. }\end{array}$ & 1 \\
\hline k. the total amount of goodwill that is expected to be deductible for tax purposes. & 2 \\
\hline $\begin{array}{l}\text { 1. for transactions that are recognised separately from the acquisition of assets and assumption of } \\
\text { liabilities in the business combination in accordance with paragraph 51: (i) a description of each } \\
\text { transaction; (ii) how the acquirer accounted for each transaction; (iii) the amounts recognised for each } \\
\text { transaction and the line item in the financial statements in which each amount is recognised; and (iv) } \\
\text { if the transaction is the effective settlement of a pre-existing relationship, the method used to } \\
\text { determine the settlement amount. }\end{array}$ & 2 \\
\hline $\begin{array}{l}\text { m. the disclosure of separately recognised transactions required by (1) shall include the amount of } \\
\text { acquisition-related costs and, separately, the amount of those costs recognised as an expense and the } \\
\text { line item or items in the statement of comprehensive income in which those expenses are recognised. } \\
\text { The amount of any issue costs not recognised as an expense and how they were recognised shall also } \\
\text { be disclosed. }\end{array}$ & 2 \\
\hline $\begin{array}{l}\mathrm{n} \text {. in a bargain purchase (see paragraphs } 34-36 \text { ): (i) the amount of any gain recognised in accordance } \\
\text { with paragraph } 34 \text { and the line item in the statement of comprehensive income in which the gain is } \\
\text { recognised; and (ii) a description of the reasons why the transaction resulted in a gain. }\end{array}$ & 2 \\
\hline $\begin{array}{l}\text { o. for each business combination in which the acquirer holds less than } 100 \text { per cent of the equity } \\
\text { interests in the acquiree at the acquisition date: (i) the amount of the non-controlling interest in the }\end{array}$ & 1 \\
\hline
\end{tabular}


acquiree recognised at the acquisition date and the measurement basis for that amount; and (ii) for each non-controlling interest in an acquiree measured at fair value, the valuation techniques and key model inputs used for determining that value.

p. in a business combination achieved in stages: (i) the acquisition-date fair value of the equity interest in the acquiree held by the acquirer immediately before the acquisition date; and (ii) the amount of any gain or loss recognised as a result of remeasuring to fair value the equity interest in the acquiree held by the acquirer before the business combination (see paragraph 42) and the line item in the statement of comprehensive income in which that gain or loss is recognised.

q. the following information: (i) the amounts of revenue and profit or loss of the acquiree since the acquisition date included in the consolidated statement of comprehensive income for the reporting period; and (ii) the revenue and profit or loss of the combined entity for the current reporting period as though the acquisition date for all business combinations that occurred during the year had been as of the beginning of the annual reporting period.

B65 For individually immaterial business combinations occurring during the reporting period that are material collectively, the acquirer shall disclose in aggregate the information required by paragraph B64(e)-(q).

B66 If the acquisition date of a business combination is after the end of the reporting period but before the financial statements are authorised for issue, the acquirer shall disclose the information required by paragraph B64 unless the initial accounting for the business combination is incomplete at the time the financial statements are authorised for issue. In that situation, the acquirer shall describe which disclosures could not be made and the reasons why they cannot be made.

B67 To meet the objective in paragraph 61, the acquirer shall disclose the following information for each material business combination or in the aggregate for individually immaterial business combinations that are material collectively:

if the initial accounting for a business combination is incomplete (see paragraph 45) for particular assets, liabilities, non-controlling interests or items of consideration and the amounts recognised in the financial statements for the business combination thus have been determined only provisionally: (i) the reasons why the initial accounting for the business combination is incomplete; (ii) the assets, liabilities, equity interests or items of consideration for which the initial accounting is incomplete; and (iii) the nature and amount of any measurement period adjustments recognised during the reporting period in accordance with paragraph 49.

for each reporting period after the acquisition date until the entity collects, sells or otherwise loses the right to a contingent consideration asset, or until the entity settles a contingent consideration liability or the liability is cancelled or expires: (i) any changes in the recognised amounts, including any differences arising upon settlement; (ii) any changes in the range of outcomes (undiscounted) and the reasons for those changes; and (iii) the valuation techniques and key model inputs used to measure contingent consideration.

for contingent liabilities recognised in a business combination, the acquirer shall disclose the information required by paragraphs 84 and 85 of IAS 37 for each class of provision.

a reconciliation of the carrying amount of goodwill at the beginning and end of the reporting period showing separately: (i) the gross amount and accumulated impairment losses at the beginning of the reporting period. (ii) additional goodwill recognised during the reporting period, except goodwill included in a disposal group that, on acquisition, meets the criteria to be classified as held for sale in accordance with IFRS 5 Non-current Assets Held for Sale and Discontinued Operations. (iii) adjustments resulting from the subsequent recognition of deferred tax assets during the reporting period in accordance with paragraph 67. (iv) goodwill included in a disposal group classified as held for sale in accordance with IFRS 5 and goodwill derecognised during the reporting period without having previously been included in a disposal group classified as held for sale. (v) impairment losses recognised during the reporting period in accordance with IAS 36. (IAS 36 requires disclosure of information about the recoverable amount and impairment of goodwill in addition to this requirement.) (vi) net exchange rate differences arising during the reporting period in accordance with IAS 21 The Effects of Changes in Foreign Exchange Rates. (vii) any other changes in the carrying amount during the reporting period. (viii) the gross amount and accumulated impairment losses at the end of the reporting period. 
Nistorenco, T.: Compliance with Disclosure Requirements under IFRS 3 of Companies Trading at Prague Stock Exchange

the amount and an explanation of any gain or loss recognised in the current reporting period that both: 2 (i) relates to the identifiable assets acquired or liabilities assumed in a business combination that was effected in the current or previous reporting period; and (ii) is of such a size, nature or incidence that disclosure is relevant to understanding the combined entity's financial statements. 